\title{
Light hydrocarbons in gas-emissions from volcanic areas and geothermal fields
}

\author{
BRUNo CAPACCIONI ${ }^{1}$, MARINO MARTINI ${ }^{2}$, FilipPo MANGANI ${ }^{3}$, \\ LUCIANO GIANNINI ${ }^{2}$, GiovanNi NAPPI ${ }^{1}$ and Franco Prati ${ }^{2}$ \\ Institute of Mineralogy and Petrography, University of Urbino, via Oddi 14, Urbino', \\ Department of Earth Sciences, University of Florence, via La Pira 4, Florence ${ }^{2}$, and \\ Institute of Chemical Sciences, University of Urbino, P. Rinascimento 6, Urbino ${ }^{3}$, Italy
}

(Received June 29, 1992; Accepted December 10, 1992)

\begin{abstract}
Geochemical investigation of gas emissions at low temperatures in areas of Quaternary volcanism shows a systematic enrichment of aromatic hydrocarbons and alkenes in fumaroles from active volcanic areas (Vulcano and Phlegrean Fields, Italy; S. Miguel, Terceira and Graciosa, Azores; Chichòn, Mexico; Uzon and Geyser Valley, Kamchatka) and geothermal systems (Larderello area, Italy) with respect to those pertaining to areas of recent but exhausted volcanism (Vulsini and Sabatini volcanic districts, Torre Alfina volcano, Italy). The general behaviour of hydrocarbons in the investigated gas-emissions, together with thermodynamic and experimental data (taken from the industrial treatment of petroleum) suggest possible abiogenic processes acting on degradation of alkane hydrocarbons when source temperatures exceed $150^{\circ}$ and acid species together with high active-surface area clay minerals are available. Benzene shows very similar enrichments in emissions from Vulcano beach and Phlegrean Fields, Kamchatka and Azores, pointing out the possible occurrence of catalytic reactions at the source. Alkenes display significant relative increases in crater fumaroles from Chichòn volcano. Moreover, lower carbon-number alkenes (propene and ethene) progressively appear with increasing alkenes/alkanes ratio, suggesting an increasing importance of thermal-cracking reactions. The general similarities in distribution patterns from different active volcanic environments allow us to reappraise the influence of the nature of sources and to emphasize the effects of abiogenic reactions.

With reference to areas of active volcanism, the distribution of hydrocarbons can represent a useful parameter to evaluate the prevailing physico-chemical conditions and their time-space variabilities. Accordingly they can give a significant contribution to the geochemical monitoring of active volcanic areas.
\end{abstract}

\section{INTRODUCTION}

Natural gaseous emissions have been currently investigated for geothermal purposes or geochemical surveillance of active volcanoes, and significant information is available on the chemical composition of fumarolic gases in a wide range of temperature (Martini et al., 1980; 1984; 1991; Carapezza et al., 1981; Le Guern et al., 1982; Gerlach, 1982; Giggenbach et al., 1986; Matsuo, 1988). With reference to light hydrocarbons, however, only few data have been provided. Ellis (1957) and Matsuo (1961), who firstly discussed the chemical composition of fumarolic gases in terms of equilibrium ther- modynamics, suggested that methane detected at Showanshinzan (Japan) and Wairakei (New Zealand) might have an extra-magmatic origin. Giggenbach et al. (1986) also agreed with this conclusion and hypothesized the occurrence of two main end members mixing into a cooler twophase hydrothermal zone surrounding the magmatic system: a magmatic component characterized by the presence of $\mathrm{H}_{2} \mathrm{~S}$ and $\mathrm{SO}_{2}$, low contents of methane and an hydrothermal component low in $\mathrm{SO}_{2}$ but high in methane. The kinetics of reactions involving methane are very slow, and equilibrium is approached only within the slow moving two-phase hydrothermal zone, where redox conditions are controlled by rock 
composition. Equilibrium is on the contrary quenched within a magmatic gas phase rapidly ascending towards the earth's surface. Tedesco and Sabroux (1987) suggested a re-examination of the influence of catalysis on the FischerTropsch synthesis of methane by hydrogenation of carbon dioxide during the fluid uprising. According to Martini et al. (1986), the flow of magmatic gases through an aquifer leads to a selective absorption of highly soluble acid gases, such as $\mathrm{SO}_{2}, \mathrm{HCl}$ and $\mathrm{HF}$, and to a consequent enrichment of slightly soluble species, such as $\mathrm{H}_{2}, \mathrm{~N}_{2}, \mathrm{O}_{2}$ and methane in the residual gas phase. The same authors interpreted methane as the result of decaying organic matter.

However, sufficient information on the presence of light hydrocarbons in natural gas emissions is not available. In this paper new data are presented and discussed on the concentration and distribution of these chemical components in fumarolic gases from active and recent volcanic systems as well as geothermal areas not directly related to volcanic activity (Table 1).

\section{Volcanic Activities}

\section{Active volcanic areas}

The last eruptive activity occurred at

Table 1. Description of the samples investigated

\begin{tabular}{|c|c|c|c|}
\hline Sample & Location & Typology & Date of sampling \\
\hline \multicolumn{4}{|c|}{ Active volcanic areas } \\
\hline RJ1 & Vulcano beach (Italy) & Bubbling gases & February 1991 \\
\hline FM1 & Vulcano beach (Italy) & Submarine emission & February 1991 \\
\hline BG4 & $\begin{array}{l}\text { Phlegrean Fields (Italy) } \\
\text { (Solfatara crater) }\end{array}$ & Fumarolas & January 1992 \\
\hline PS4 & $\begin{array}{l}\text { Phlegrean Fields (Italy) } \\
\text { (Pisciarelli site) }\end{array}$ & Bubbling gases & January 1992 \\
\hline KUZ & Uzon caldera (Kamchatka) & Bubbling gases & October 1990 \\
\hline KGV & Geyser Valley (Kamchatka) & Fumarolas & October 1990 \\
\hline FU & $\begin{array}{l}\text { S. Miguel island (Azores) } \\
\text { (Furnas site) }\end{array}$ & Bubbling gases & October 1991 \\
\hline ES & $\begin{array}{l}\text { S. Miguel island (Azores) } \\
\text { (Esguicho site) }\end{array}$ & Bubbling gases & October 1991 \\
\hline RG & $\begin{array}{l}\text { S. Miguel island (Azores) } \\
\text { (Ribeira Grande site) }\end{array}$ & Bubbling gases & October 1991 \\
\hline $\mathrm{CV}$ & $\begin{array}{l}\text { S. Miguel island (Azores) } \\
\text { (Caldera Velha site) }\end{array}$ & Bubbling gases & October 1991 \\
\hline GR & $\begin{array}{l}\text { Graciosa island (Azores) } \\
\text { (Graciosa caldera site) }\end{array}$ & Fumarolas & October 1991 \\
\hline TE & $\begin{array}{l}\text { Terceira island (Azores) } \\
\text { (Terceira caldera) }\end{array}$ & Fumarolas & October 1991 \\
\hline $\mathrm{CH} 1$ & Chichòn volcano (Mexico) & Bubbling gases & November 1991 \\
\hline $\mathrm{CH} 3$ & Chichòn volcano (Mexico) & Fumarolas & November 1991 \\
\hline \multicolumn{4}{|c|}{ Recent volcanic areas and geothermal fields } \\
\hline LT1 & Latera caldera (Italy) & Potizza & May 1990 \\
\hline LT2 & Latera caldera (Italy) & Potizza & May 1990 \\
\hline TA & Torre Alfina volcano (Italy) & Potizza & May 1990 \\
\hline GG1 & Sabatini volc. complex (Italy) & Potizza & July 1990 \\
\hline GG2 & Sabatini volc. complex (Italy) & Potizza & July 1990 \\
\hline MZ & Manziana crater (Italy) & Potizza & July 1990 \\
\hline SPp & S. Pisano geoth. well (Italy) & Geoth. fluid & September 1990 \\
\hline SPs & S. Pisano geoth. field (Italy) & Bubbling gases & September 1990 \\
\hline MR & $\begin{array}{l}\text { Monterotondo geoth. field } \\
\text { (Italy) }\end{array}$ & Fumarolas & September 1990 \\
\hline
\end{tabular}




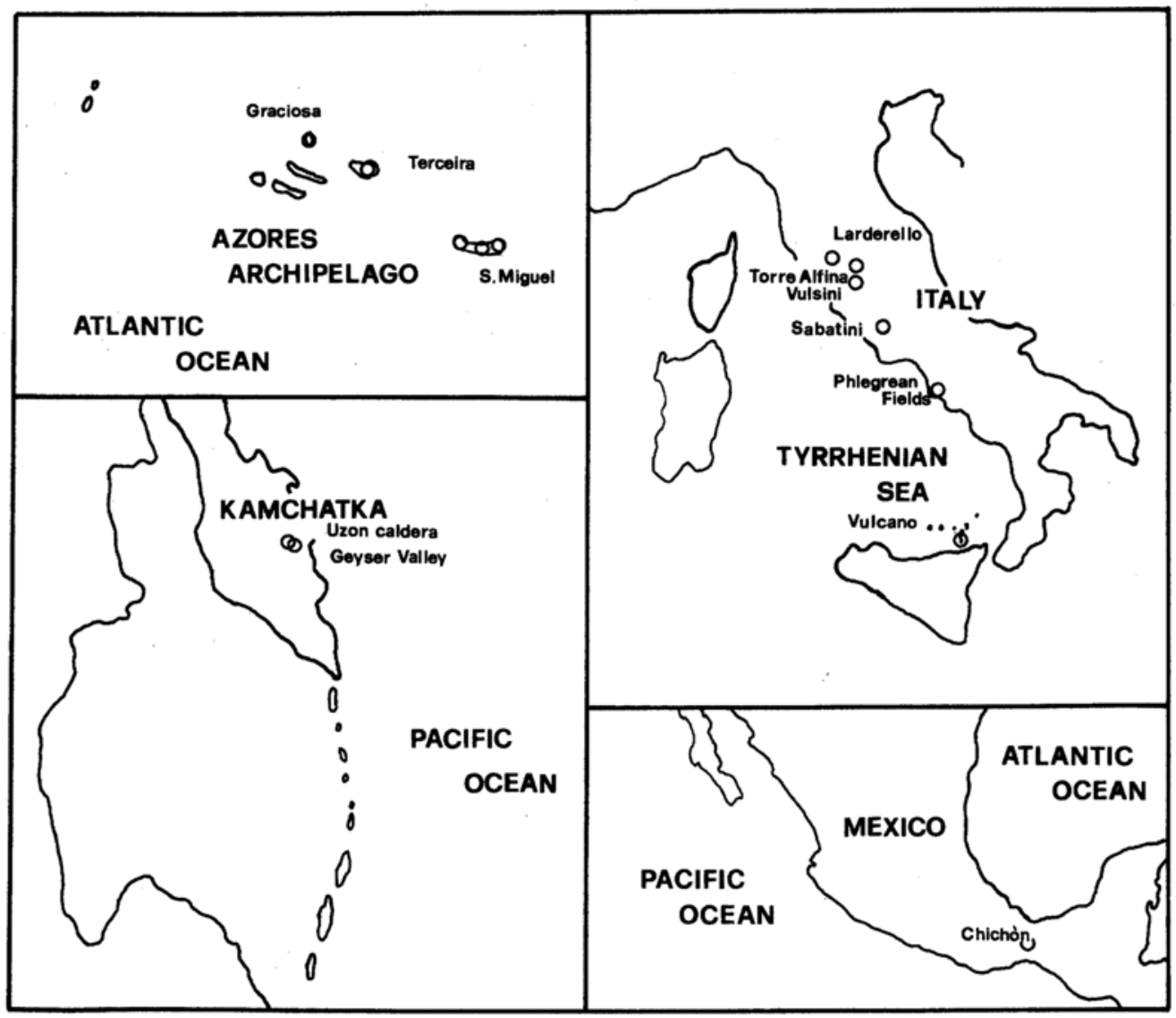

Fig. 1. Investigated areas.

Vulcano (Fig. 1) in 1888-1890 was characterized by hydromagmatic explosions, producing thin ash deposits at a distance not exceeding few hundred meters from the vent (Frazzetta et al., 1984; Dellino et al., 1990). After this last eruptive period, the volcanic system remained in a fumarolic stage with the main clusters of emissions located on the northern crater rim and near Baia di Levante beach. The crater fumaroles have shown interesting time- and space-related variations (Martini et al., 1980; Carapezza et al., 1981; Cioni and D'Amore, 1984). However, due to their almost complete lack of hydrocarbons our attention has been devoted to the beach manifestations.

Phlegrean Fields are located inside a huge caldera (Fig. 1), possibly related to a giant ignimbrite eruption 35,000 years ago (Rosi et al., 1983). The last eruptive event occurred in 1538 with the build up of Monte Nuovo, a $140 \mathrm{~m}$ high tuff cone. At present, gas emissions are located inside and just outside the Solfatara crater (Bocca Grande, $159^{\circ} \mathrm{C}$, and Pisciarelli, $98^{\circ} \mathrm{C}$, respectively). Their physico-chemical characters suggested an origin from boiling aquifers (Martini et al., 1984).

The axis of the Mid-Atlantic ridge crosses the Azores submarine plateau in a north-south direction (Fig. 1). The hystorical documentation on volcanic activity started after the Portuguese settlement in 15th century, and only ten volcanoes are considered still active. Besides the surtseyan eruption of Capelinhos at Faial in 1957-58 (Machado and Forjaz, 1968), strombolian activity with lava flows occurred in 1761 at Terceira, four explosive eruptions were recorded for San Miguel in 1563,1638, 1640 and 1811, and solfataric activity was reported for Graciosa 
(Booth et al., 1983; Forjaz pers. comm.).

Chichòn volcano (Fig. 1) consists almost entirely of pyroclastic deposits and lava domes, directly overlying the sedimentary substratum. It erupted explosively on March 29, 1982, after a period of quiescence of about 350 years, and produced a pumiceous fallout followed by surges and pyroclastic flows. At present an intense fumarolic activity occurs inside the crater (Carey and Sigurdsson, 1986).

The manifestations at Uzon caldera and Geyser Valley, Kamchatka (Fig. 1) with bubbling gases, steaming pools and geysers can be considered as related to active volcanism, although no information about their volcanic histories is available (Piip, 1937; Vakin et al., 1982).

\section{Areas of recently exhausted volcanism}

Gaseous emissions in these areas are represented by surface manifestations of residual thermal anomalies and characterized by almost pure $\mathrm{CO}_{2}$ (mofettas) or by $\mathrm{CO}_{2}$ plus $\mathrm{H}_{2} \mathrm{~S}$ (potizzas).

The Latera caldera (Fig. 1) consists of a huge polygenetic structure produced by a series of ignimbrite-forming eruptions (Sparks, 1975; Metzeltin and Vezzoli, 1983; Nappi et al., 1991) occurring during a period of about $0.17 \mathrm{~m}$.y. Its youngest activity has been dated at 110,000 years ago (Santi, 1990).

Other samples pertain to the small quaternary center of Torre Alfina (Fig. 1), whose products are only represented by minor lava flows.

Explosive paroxysmal eruptions with subordinate effusive episodes characterized the Sabatini Volcanic District (Fig. 1) during a period of $0.6 \mathrm{~m} . \mathrm{y}$., and the development of the volcano-tectonic depression of Bracciano lake followed the exhaustion of the eruptive activity about 40,000 years ago (De Rita and Funiciello, 1985).

\section{Geothermal areas not related to recent volcanism}

Geothermal wells at Monterotondo and Sasso Pisano, pertaining to the well known area of Larderello (Fig. 1), are mainly vapour- dominated systems. The productive, high permeability aquifer is located in Triassic evaporites covered by impervious shales of allochtonous series (Ligurids). The bottomhole temperatures often exceed $260^{\circ} \mathrm{C}$ (Squarci, 1981).

\section{Sampling and Analytical Procedures}

The sampling apparatus included a vacuum vial partially filled with $4 \mathrm{~N} \mathrm{NaOH}$ solution (Giggenbach, 1975), which might concentrate up to several hundred times the uncondensable gases, such as $\mathrm{H}_{2}, \mathrm{~N}_{2}, \mathrm{O}_{2}$ and light hydrocarbons. The total quantity of sample collected (included water vapour if present) varies from 1 to 10 grams, depending on the relative amounts of uncondensable gases.

The analysis of organic fractions was carried out with a Dani 86.10 gas chromatograph (Mangani et al., 1991) equipped with a Flame Ionization Detector (FID). A glass column ( $2 \mathrm{~m}$ long, $2 \mathrm{~mm}$ I.D.) was packed with Carbopack B $80 / 100$ mesh coated with $1 \%$ of SP 1000 . The temperature of the column was set at $30^{\circ} \mathrm{C}$ for 2 minutes and then increased up to $220^{\circ} \mathrm{C}$ with a rate of $30^{\circ} \mathrm{C} / \mathrm{min}$. The injector and detector temperatures were $150^{\circ} \mathrm{C}$ and $220^{\circ} \mathrm{C}$ respectively. Nitrogen was used as carrier gas and the flow rate was set at $30 \mathrm{ml} / \mathrm{min}$. Qualitative analysis was carried out using the retention time and the mass spectrum obtained by the gaschromatograph (GC) coupled with a double focussing mass spectrometer (MS) of a model VG 70-70 H (VG analytical Ltd., Manchester, U.K.). The MS was equipped with a Tecknivent Vector/one data system (Tecknivent, St. Louis, USA). Calibration was performed by using standard mixtures obtained with permeation tubes (Mangani and Ninfali, 1988). The very slow kinetics of possible reactions involving hydrocarbons at sample storage temperatures prevent any kind of modification after collection.

\section{Results}

Table 2 shows the analytical data for the inorganic components. Carbon dioxide concentra- 
Table 2. Main chemical composition of gases (in volume percent)

\begin{tabular}{|c|c|c|c|c|c|c|c|c|c|}
\hline \multicolumn{10}{|c|}{ Active volcanic areas } \\
\hline Sample & RJ1 & FM1 & & BG4 & PS4 & FU & \multicolumn{2}{|c|}{ ES } & RG \\
\hline temp. ${ }^{\circ} \mathrm{C}$ & 94 & 97 & & 155 & 89 & 96 & \multicolumn{2}{|c|}{98} & 95 \\
\hline $\mathrm{CO}_{2}$ & 92.88 & 94.67 & & 98.82 & 99.13 & 99.05 & \multicolumn{2}{|c|}{99.11} & 99.39 \\
\hline $\mathrm{H}_{2} \mathrm{~S}$ & 1.15 & 1.32 & & 0.59 & 0.44 & 0.43 & \multicolumn{2}{|c|}{0.53} & 0.22 \\
\hline $\mathrm{H}_{2}$ & 0.54 & 1.94 & & 0.14 & 0.14 & 0.16 & \multicolumn{2}{|c|}{0.25} & 0.30 \\
\hline $\mathrm{N}_{2}$ & 4.75 & 1.84 & & 0.28 & 0.27 & 0.35 & \multicolumn{2}{|c|}{0.09} & 0.08 \\
\hline $\mathrm{O}_{2}^{*}$ & 380 & 75 & & 0.3 & 0.8 & 8.3 & \multicolumn{2}{|c|}{2.2} & 2.1 \\
\hline $\mathrm{CO}^{*}$ & - & 0.24 & & 0.19 & - & - & \multicolumn{2}{|c|}{-} & 0.015 \\
\hline Sample & $\mathrm{CV}$ & GR & & $\mathrm{TE}$ & $\mathrm{CH} 1$ & $\mathrm{CH} 3$ & \multicolumn{2}{|c|}{ KUZ } & KGV \\
\hline temp. ${ }^{\circ} \mathrm{C}$ & 97 & 91 & & 91 & 94 & 97 & & 97 \\
\hline $\mathrm{CO}_{2}$ & 99.54 & 99.19 & & 97.59 & 78.00 & 91.28 & \multicolumn{2}{|c|}{93.23} & 94.44 \\
\hline $\mathrm{H}_{2} \mathrm{~S}$ & 0.09 & 0.13 & & 0.98 & 4.71 & 6.15 & \multicolumn{2}{|c|}{3.96} & 3.61 \\
\hline $\mathrm{H}_{2}$ & 0.13 & 0.08 & & 0.83 & 12.17 & 1.46 & \multicolumn{2}{|c|}{0.15} & 0.12 \\
\hline $\mathrm{N}_{2}$ & 0.21 & 0.48 & & 0.22 & 4.90 & 0.82 & \multicolumn{2}{|c|}{1.85} & 1.58 \\
\hline $\mathrm{O}_{2}^{*}$ & 6.3 & 112 & & 5.7 & 47 & 1.1 & \multirow{2}{*}{\multicolumn{2}{|c|}{${ }^{11}$}} & 28 \\
\hline $\mathrm{CO}^{*}$ & - & 0.017 & & 0.048 & 0.67 & 0.09 & & & - \\
\hline \multicolumn{10}{|c|}{ Recent volcanic areas and geothermal fields } \\
\hline Sample & LT1 & LT2 & TA & GG1 & GG2 & MZ & $\mathrm{SPp}$ & SPS & MR \\
\hline temp. ${ }^{\circ} \mathrm{C}$ & cold & cold & cold & cold & cold & cold & 93 & 95 & 98 \\
\hline $\mathrm{CO}_{2}$ & 94.57 & 92.55 & 93.25 & 98.29 & 98.41 & 97.13 & 88.94 & 90.76 & 89.33 \\
\hline $\mathrm{H}_{2} \mathrm{~S}$ & 0.311 & 0.301 & 0.037 & 0.086 & 0.055 & 1.097 & 2.678 & - & 1.996 \\
\hline $\mathrm{H}_{2}$ & - & - & - & - & - & - & 3.988 & 2.710 & 3.323 \\
\hline $\mathrm{N}_{2}$ & 4.390 & 5.980 & 5.290 & 0.840 & 0.788 & 1.745 & 1.026 & 4.580 & 1.713 \\
\hline $\mathrm{O}_{2}$ & 0.4505 & 0.8105 & 0.6928 & 0.0019 & 0.0004 & 0.0013 & 0.0029 & 0.1300 & 0.0310 \\
\hline
\end{tabular}

(*) values expressed in ppm.

"-" means below the detection limit.

tions in all the samples exceed $90 \%$, with minor amounts of hydrogen sulphide, nitrogen and oxygen. Not negligible contents of hydrogen and carbon monoxide are found only in active volcanic areas. This last shows maximum concentrations of $0.70 \mathrm{ppm}$ in the crater fumaroles from Chichòn volcano.

Among hydrocarbons, fifteen components pertaining to five homologous series have been identified. These components often amount to less than $1 \%$ of the total gas mixture (Tables 3 and 4). The concentrations of methane are invariably above $90 \%$ of the total organic fraction.

Normal alkanes, the second most abundant species, display decreasing contents with increasing carbon number in the homologous series. Isoalkanes are represented by isobutane and isopentane with concentrations up to thousands of ppb. Cyclo-alkanes occurring as cyclopentane and cyclohexane were detected only at the Azores and at Chichòn volcano.

Among alkenes, butene characterizes the samples from active volcanic and geothermal areas. Propene was detected at Phlegrean Fields, at San Miguel and Graciosa and at Chichòn volcano, while ethene was found only in the sample from Chichòn volcano.

Significant amounts of aromatics showed a common character of all the areas examined. Benzene was found to be an ubiquitous component, while toluene was detected in some samples only.

\section{Discussion}

Figure 2 represents the distribution of alkanes, aromatics and hydrogen, where an in- 
Table 3. Concentration of hydrocarbons (in ppm for methane and in ppb for the others)

\begin{tabular}{|c|c|c|c|c|c|c|c|}
\hline \multicolumn{8}{|c|}{ Active volcanic areas } \\
\hline Sample & RJ1 & FM1 & BG4 & PS4 & FU & ES & RG \\
\hline methane & 3720 & 2400 & 120 & 86 & 20 & 48 & 37 \\
\hline ethene & - & - & - & - & - & - & - \\
\hline ethane & 570 & 178 & 1798 & 1115 & 235 & 960 & - \\
\hline propene & - & - & 13 & - & 10 & - & - \\
\hline propane & 498 & 100 & 154 & 98 & 19 & 570 & 109 \\
\hline i-butane & 60 & 48 & 9 & 5 & - & 274 & - \\
\hline i-butene & 66 & 32 & 9 & 4 & 13 & 32 & 22 \\
\hline 1-butene & - & - & - & - & - & - & - \\
\hline tr-2-butene & - & - & - & - & - & - & - \\
\hline cs-2-butene & - & - & - & - & 2 & - & 9 \\
\hline $\begin{array}{l}\text { n-butane } \\
\text { cyclopen- }\end{array}$ & 78 & 8 & 16 & 10 & - & 172 & - \\
\hline tane & - & - & - & - & - & 14 & 2 \\
\hline i-pentane & 12 & 2 & - & - & 2 & 81 & 2 \\
\hline n-pentane & 18 & 6 & 1 & - & 2 & 74 & 3 \\
\hline cyclohexane & - & - & - & - & 51 & 21 & 12 \\
\hline benzene & 2889 & 763 & 2020 & 1032 & 303 & 373 & 164 \\
\hline toluene & - & - & - & - & 115 & 176 & 148 \\
\hline Sample & $\mathrm{CV}$ & GR & TE & $\mathrm{CH} 1$ & $\mathrm{CH} 3$ & KUZ & KGV \\
\hline methane & 19 & 27 & 3700 & 38 & 11 & 7900 & 3300 \\
\hline ethene & - & - & - & 1244 & - & - & - \\
\hline ethane & 204 & - & 5913 & 1486 & 465 & 18750 & 9900 \\
\hline propene & - & 22 & - & 1054 & 62 & - & - \\
\hline propane & 32 & 52 & 50 & 484 & 64 & 274 & 1320 \\
\hline i-butane & 2 & 2 & 9 & 155 & 21 & 17 & - \\
\hline i-butene & 7 & 6 & 71 & 553 & 52 & 21 & - \\
\hline 1-butene & - & - & - & 190 & 25 & - & - \\
\hline tr-2-butene & - & - & - & 104 & 11 & - & - \\
\hline cs-2-butene & 55 & - & 94 & 294 & 34 & - & - \\
\hline $\begin{array}{l}\text { n-butane } \\
\text { cyclopen- }\end{array}$ & 3 & 5 & 6 & 294 & 57 & 21 & 660 \\
\hline tane & - & - & - & 155 & 3 & - & - \\
\hline i-pentane & 1 & 5 & 13 & 397 & 9 & 8 & - \\
\hline n-pentane & 2 & 18 & 10 & 397 & 8 & 4 & 330 \\
\hline cyclohexane & 18 & 21 & 51 & 2488 & 78 & - & - \\
\hline benzene & 248 & 156 & 998 & 2332 & 319 & 11390 & 4290 \\
\hline toluene & 17 & 114 & - & - & - & - & - \\
\hline
\end{tabular}

"_-" means below the detection limit.

crease of both aromatics and hydrogen can be observed from areas of recent volcanism, to geothermal areas and to active volcanic areas. After an increase of both hydrogen and aromatics, a sharp shift towards the hydrogen corner occurs for samples collected at volcanic systems where historical activities are reported. These two trends can be tentatively interpreted by considering an initial common and then indipendent sources for aromatics and hydrogen.
The increase of aromatics with respect to alkanes passing from recent to active volcanic areas, already pointed out in Fig. 2, is shifted sharply towards the alkenes corner in Fig. 3. The samples from Chichòn volcano show the maximum shift. However the evidence of historical records of volcanic activities does not provide a sufficient explanation; in fact the samples from Vulcano show a lower increase in alkenes than those from the Azores where eruptive episodes 
Table 4. Concentration of hydrocarbons (in ppm for methane and in ppb for the others)

\begin{tabular}{lccccccccc}
\hline \multicolumn{8}{c}{ Recent volcanic areas and geothermal fields } \\
\hline Sample & LT1 & LT2 & TA & GG1 & GG2 & MZ & SPp & SPs & MR \\
\hline methane & 0.280 & 0.360 & 0.730 & 0.786 & 0.749 & 0.027 & 3.367 & 2.010 & 3.606 \\
ethane & 31343 & 39388 & 8254 & 7484 & 4526 & 1481 & 100572 & 89930 & 40809 \\
propane & 5278 & 6775 & 3050 & 203 & 212 & 41 & 22178 & 6566 & 5393 \\
i-buthane & 439 & 674 & 529 & 116 & 109 & 5 & 7127 & 1897 & 789 \\
i-butene & - & - & - & - & - & 7 & 87 & 874 & 737 \\
n-buthane & 1057 & 1302 & 606 & 116 & 117 & 7 & 4292 & 1255 & 1448 \\
i-pentane & 247 & 286 & 290 & 177 & 176 & 1 & 1396 & 418 & 286 \\
n-pentane & 276 & 342 & 161 & 98 & 95 & 1 & 1014 & 298 & 191 \\
cyclohexane & 21 & 25 & 64 & 93 & 88 & - & 251 & 158 & 147 \\
benzene & 42 & 46 & 193 & 151 & 146 & 10 & 2081 & 2762 & 5115 \\
n-hexane & 100 & 68 & - & 132 & 152 & - & 503 & 242 & - \\
toluene & - & - & 171 & 146 & 137 & - & 1193 & 1730 & 1609 \\
\hline
\end{tabular}

"-_" means below the detection limit.

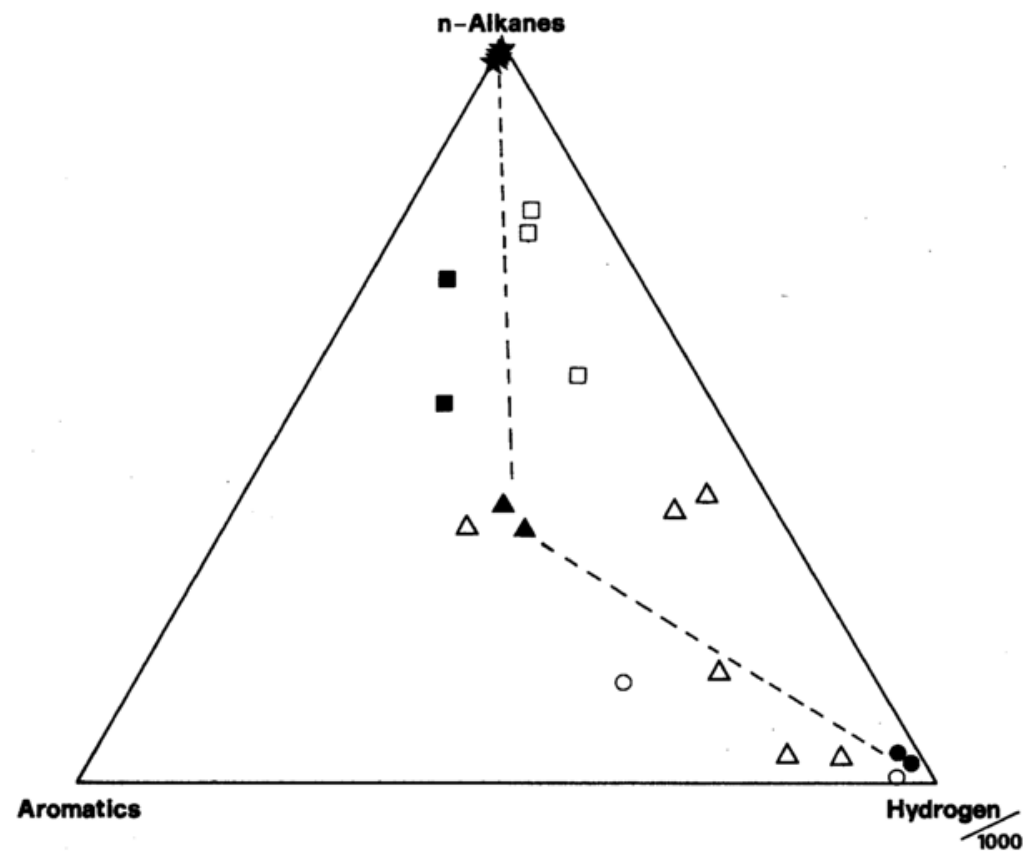

Fig. 2. Relative distribution of normal alkanes, aromatic hydrocarbons and hydrogen for all the investigated samples. Closed stars: recently exhausted volcanic areas; closed squares: Uzon and Geyser Valley; closed triangles: Phlegrean Fields; open circles: Vulcano island; open triangles: Azores islands; closed circles: El Chichòn volcano.

are dated back to much earlier time.

Information from industrial processes of oil refineries can provide some details about the parameters controlling possible reactions between different hydrocarbons (Girelli, 1969). Two main types of processes can be considered: catalytic reforming and thermal cracking. Temperature, hydrogen partial pressure, and several catalytic agents represent the controlling parameters. Catalytic reforming includes different processes in which catalytic agents, rather than temperature and pressure, play the 


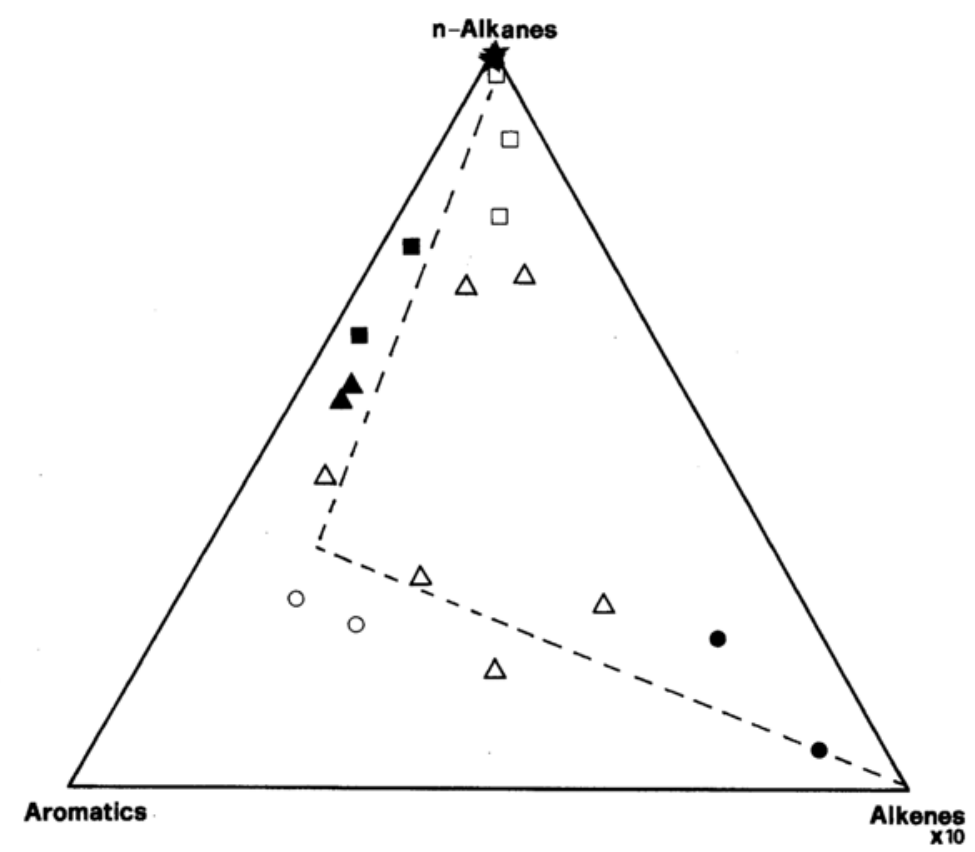

Fig. 3. Relative distribution of normal alkanes, aromatics and alkenes. Closed stars: recently exhausted volcanic areas; closed squares: Uzon and Geyser Valley; closed triangles: Phlegrean Fields; open circles: Vulcano island; open triangles: Azoresislands; closed circles: El Chichòn volcano.

most important role. The main reactions involved are the following (Girelli, 1969):

$$
\begin{aligned}
& \mathrm{C}_{6} \mathrm{H}_{12} \rightarrow \mathrm{C}_{6} \mathrm{H}_{6}+3 \mathrm{H}_{2} \\
& \mathrm{C}_{6} \mathrm{H}_{14} \rightarrow \mathrm{C}_{6} \mathrm{H}_{12}+\mathrm{H}_{2} \rightarrow \mathrm{C}_{6} \mathrm{H}_{6}+4 \mathrm{H}_{2}
\end{aligned}
$$

These consist respectively of dehydrogenation of $\mathrm{C}_{6}$ cycloalkanes (1) and of dehydrocyclization of normal alkanes (2), to produce benzene and hydrogen. The best industrial results are obtained in the temperature range of $450-500^{\circ} \mathrm{C}$, hydrogen partial pressure from 15 to $40 \mathrm{~atm}$ and catalytic agents composed by platinum supported by aluminum beds impregnated with halogen acids. Intermediate products of reactions (1) and (2) are represented by iso- and cyclo-alkanes.

Processes of thermal cracking consist on the breakage of carbon-carbon bond ("cracking", s.s.) and the breakage of carbon-hydrogen bond:

$$
\begin{aligned}
& \mathrm{C}_{8} \mathrm{H}_{18} \rightarrow \mathrm{C}_{7} \mathrm{H}_{14}+\mathrm{CH}_{4} \\
& \mathrm{C}_{3} \mathrm{H}_{8} \rightarrow \mathrm{C}_{3} \mathrm{H}_{6}+\mathrm{H}_{2} .
\end{aligned}
$$

The first is prevailing during thermal cracking of high carbon number molecules, while the second is preferred when low carbon number molecules represent the starting material. The industrial reactions are carried out at temperatures of the order of $1000^{\circ} \mathrm{C}$. As shown by reactions (3) and (4) the most important products of thermal cracking are represented by alkenes, hydrogen and methane.

Several authors (Weiss and Roloff, 1963; Sarkisyan, 1972; Blank et al., 1973; Zimmerle, 1985) stressed the importance of clay minerals as catalysts during the transformation of organic matter. In particular Hunt (1979) concluded that smectite-type clay minerals can play an important role in the production of hydrocarbons from organic matter, due to their large active surface area.

From a thermodynamic point of view, the relative stabilities of alkanes, aromatics and alkenes, can be well expressed in the diagram of Fig. 4, where the variation of free energies of formations for carbon atom is reported against tem- 


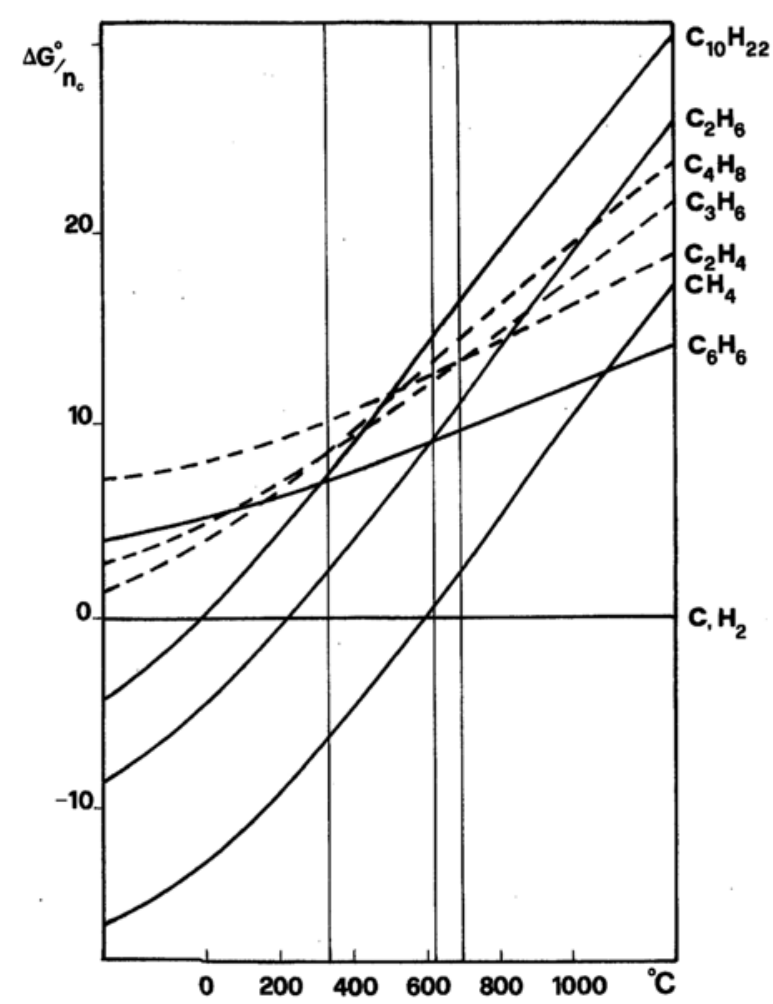

Fig. 4. Relationships between free energies of formation (expressed as $\mathrm{Kcal} / \mathrm{g}$ for each carbon atom) and temperature for different compounds (modified from Girelli, 1969).

perature (Girelli, 1969). According to its relatively high concentrations observed in any of the gas emissions investigated, methane appears as the component with the highest stability at any temperature. Ethane appears also more stable with respect to benzene and alkenes up to $600^{\circ} \mathrm{C}$, while at temperatures above $350^{\circ} \mathrm{C}$ the stability of benzene is greater with respect to high carbon number normal alkanes. Among alkenes, always less stable than normal alkanes, butene is prevailing below $350^{\circ} \mathrm{C}$; propene in the temperature interval $350-700^{\circ} \mathrm{C}$ and ethene above $700^{\circ} \mathrm{C}$ display relatively higher stabilities.

Among the above mentioned conditions, the occurrence of acid species, metals, hydrogen, as well as fine-grained smectites (Capaccioni et al., 1991) at relatively high temperatures, can be normally observed in the environments of active volcanoes and, at a lower extent, in geothermal areas. The distribution of hydrocarbons in gaseous emissions here considered could then mainly result from abiogenic reactions occurring at the prevailing conditions of the different systems. The source of hydrocarbons can be organic matter rapidly buried by volcanoclastic sediments (Zimmerle, 1985) in volcanic areas, or contained in the sedimentary rocks of geothermal fields.

The relative depletion in alkanes, the increase of aromatics and of alkenes passing from recent to active volcanic areas, could be related to the fulfilment of thermal and catalytic conditions able to trigger reactions of the type (1) to (4). In particular, the maximum enrichment of benzene at Vulcano beach (Fig. 2) could result from the occurrence of catalysts in the source aquifer (reactions 1 and 2), such as soluble acid species $\left(\mathrm{SO}_{2}, \mathrm{HCl}\right.$ and $\left.\mathrm{HF}\right)$ and clay minerals (mainly smectites). On the contrary, alkenes enrichment seems to be mainly related to thermal effects (reactions 3 and 4), as suggested by the displacing of crater fumaroles of Chichòn volcano towards the alkenes corner (Fig. 3). This conclusion well agrees with the relatively high contents of components equilibrated at high temperatures, such as carbon monoxide and hydrogen (Tedesco and Sabroux, 1987), and with the progressive appearance of lighter alkenes (propene and ethene), whose relative stabilities are reversed with increasing temperature (Fig. 4). Moreover, the occurrence of cyclohexane could testify an incomplete reaction of type (2). The relative thermodynamic stabilities seem to suggest the increase of aromatics/alkanes ratio in gases from active volcanic areas (Fig. 2) as resulting from processes occurring at minimum temperatures of $350^{\circ} \mathrm{C}$, even if the temperatures of the reactions (1) and (2) can be lowered by catalysts. Moreover, the present aromatics/alkanes ratios may result from an independent depletion of alkanes due to reactions of type (3) and (4). Finally, hydrogen and methane always appear as final products of all the reactions considered. 


\section{Conclusions}

The results obtained through the investigation of gaseous emissions from different volcanic environments suggest the following inferences: 1) no evidences disagree with an origin of hydrocarbons from decaying of organic matter; 2) the composition of hydrocarbons in volcanic gases appears to be mainly controlled by the physico-chemical conditions occurring during their generation and uprising towards the surface, while their total contents seem to be related with the amounts of organic matter available at the source; 3) fumaroles interpreted as supplied by extensive boiling aquifers show the highest relative increase of aromatics, probably due to catalytic and thermal reactions of the type (1) and (2);4) suitable catalysts seems to occur in active volcanoes, where acid species $\left(\mathrm{SO}_{2}, \mathrm{HCl}\right.$ and $\mathrm{HF}$ ) in the uprising fluids and smectites and other clay minerals in the hosting rocks are available; 5) high temperature fluids reaching the surface after minor interactions with aquifers (crater fumaroles) point out a significant increase of alkenes together with a gradual appearance of propene and ethene; in this case thermal reactions of the type (3) and (4) are expected to prevail.

The systematic increase of benzene, the appearance of butene and propene, and the relative decrease in normal and iso-alkanes concentrations passing from areas of recent volcanism to presently active volcanic areas, seem to indicate general processes affecting the organic fraction of gaseous emissions, favoured by temperatures in the range of $250-500^{\circ} \mathrm{C}$, with acid species and probably clay minerals (mainly smectites) acting as catalysts.

According to the available data on the free energies of formation, further increases in concentrations of alkenes with respect to aromatics should correspond to processes occurring at higher reaction temperatures.

Mofettas and potizzas from areas of recently exhausted volcanism do not show evidences of significant catalytic and thermal reactions among normal alkanes. Gases from Larderello geothermal field point out a minor increase of species, such as aromatics and alkenes, produced by catalytic and thermal reactions, while the highest total amount of hydrocarbons can be related to a high content of organic matter available in the sedimentary source rocks. Catalytic and thermal reactions affect gases from Vulcano beach, Phlegrean Fields, Uzon caldera, Geyser Valley, Terceira and Graciosa, probably due to significant accumulation of acid species in the boiling aquifers, leading to a severe argillification of hosting rocks. Finally, at Chichòn volcano and at a minor extent at S. Miguel island, reactions dominated by thermal cracking of normal alkanes seem to represent the prevailing processes.

Acknowledgments-This work was financially supported by Gruppo Nazionale Vulcanologia, and C.N.R. Centro di Studio per la Minerogenesi e la Geochimica Applicata.

\section{REFERENCES}

Blank, P., Lehmann, G. and Starke, R. (1973) Tonminerale und organische substanz. Z. Geol. Wiss. Berlin 1, (1), 55-63.

Booth, B., Croasdale, R. and Walker, G. P. L. (1983) Volcanic hazard on Sao Miguel, Azores. Forecasting Volcanic Events, (Tazieff H. and Sabroux J. C. ed.) Elsevier, 99-109.

Capaccioni, B., Coniglio, S. and Fratini, F. (1991) Clay minerals on recent products of hydromagmatic activity: considerations on their genesis. Acta Vulcanol. 1, 69-77.

Carapezza, M., Nuccio, M. and Valenza, M. (1981) Genesis and evolution of the fumaroles of Vulcano (Aeolian islands, Italy); a geochemical model. Bull. Volcanol. 44, 548-563.

Carey, S. and Sigurdsson, H. (1986) The 1982 eruption of El Chichòn volcano, Mexico (2): observations and numerical modelling of tephra-fall distribution. Bull. Volcanol. 48, 127-141.

Cioni, R. and D'Amore, F. (1984) A genetic model for the crater fumaroles of Vulcano island (Sicily, Italy). Geothermics 13, 375-384.

Dellino, P., Frazzetta, G. and La Volpe, L. (1990). Wet surge deposits at La Fossa di Vulcano: depositional and eruptive mechanisms. J. Volcanol. Geotherm. Res. 43, 215-233.

De Rita, D. and Funiciello, R. (1985) The Sabatini 
volcanic complex. "Excursions Guidebook", IAVCEI, 1985 Scientific Assembly, Giardini Naxos, Italy 24-31.

Ellis, A. J. (1957) Chemical equilibrium in magmatic gases. Am. J. Science 255, 416-431.

Frazzetta, G., La Volpe, L. and Sheridan, M. F. (1984) Evolution of Fossa cone, Vulcano. J. Volcanol. Geotherm. Res. 17, 329-360.

Gerlach, T. M. (1982) Interpretation of Volcanic Gas Data from Tholeiitic and Alkaline Mafic Lavas. Bull. Volcanol. 45, 236-244.

Giggenbach, W. F. (1975) A simple method for the collection and analysis of volcanic gas samples. Bull. Volcanol. 39, 132-145.

Giggenbach, W. F., Martini, M. and Corazza, E. (1986) The effects of hydrothermal processes on the chemistry of some recent volcanic gas discharges. Per. Mineral. 55, 15-28.

Girelli, A. (1969) Petrolio e petrolchimica. Trattato di chimica industriale e applicata. (Zanichelli, Ed.), 2, 929-1126.

Hunt, J. M. (1979) Petroleum Geochemistry and Geology. Freeman and Co., 617 pp., San Francisco.

Le Guern, F., Nohl, A. and Bicocchi, P. (1982) Field Measurements of Volcanic Gases. Vulcano Island (Italy), Kilauea (Hawaii, U.S.A.), Merapi ( Java, Indonesia). Bull. Volcanol. 45, 230-233.

Machado, F. and Forjaz, V. H. (1968) Actividade vulcanica do Faial-1957-67. Porto.

Mangani, F. and Ninfali, P. (1988) Gas chromatographic determination of acetaldehyde and acetone in human blood by purge and trap, using permeation tubes for calibration. $J$. Chromatogr. 437, 294.

Mangani, F., Cappiello, A., Capaccioni, B. and Martini, M. (1991) Sampling and analysis of light hydrocarbons in volcanic gases. Chromatographia 32, 441-444.

Martini, M., Piccardi, G. and Cellini, Legittimo, P. (1980) Geochemical surveillance of active volcanoes: data on the fumaroles of Vulcano (Aeolian Island, Italy). Bull. Volcanol. 43, 255263.

Martini, M., Cellini, Legittimo P., Piccardi, G. and Giannini L. (1984) Composition of hydrothermal fluids during the bradyseismic crisis which commenced at Phlegrean Fields in 1982. Bull. Volcanol. 47, 267-273.

Martini, M., Cellini, Legittimo P., Piccardi, G. and Giannini L. (1986) The fumaroles of Vulcano (Italy): differences in chemical compositions produced by the surface environment. Geothermics 15, 205-209.

Martini, M., Giannini, L., Buccianti, A., Prati, F.,
Cellini, Legittimo P., Iozzelli, P. and Capaccioni, B. (1991) 1980-1990: ten years of geochemical investigation at Phlegrean Fields (Italy). J. Volcanol. Geotherm. Res. 48, 161-171.

Matsuo, S. (1961) On the chemical nature of fumarolic gases of volcano Showashinzan, Hokkaido, Japan. Jour. Earth Sci. Nagoya Univ. 8, 80100.

Matsuo, S. (1988) Activity report of Japanese Group for the chemical prediction of volcanic eruption. Per. Mineral. 55, 39-53.

Metzeltin, S. and Vezzoli, L. (1983) Contributi alla geologia del vulcano di Latera (Monti Vulsini, Toscana meridionale-Lazio settentrionale). Mem. Soc. Geol. Ital. 25, 247-271.

Nappi, G., Renzulli, A. and Santi, P. (1991) Evidence of incremental growth in the Vulsinean calderas (Central Italy). J. Volcanol. Geotherm. Res. 47, 13-31.

Piip. B. I., (1937) The thermal springs in Kamchatka. SOPS AN SSSR, Ser. Kamchatka, GONTI, 268 pp. (Russian).

Rosi, M., Sbrana, A. and Principe, C. (1983) The Phlegrean Fields: structural evolution, volcanic history and mechanism. J. Volcanol. Geotherm. Res. 17, 273-288.

Santi, P. (1990) New geochronological data of the Vulsini Volcanic District (Central Italy). Proceedings of S.I.M.P. Congress, Ischia, Italy 15-18.

Sarkisyan, S. G. (1972) Origin of authigenic clay minerals and their significance in petroleum geology. Sed. Geol. 7, 1-22.

Sparks, R. S. J. (1975) Stratigraphy and geology of the ignimbrites of Vulsini Volcano, Central Italy. Geol. Rundschau 64, 497-523.

Squarci, P. (1981) Geologia e geoidrologia dei sistemi geotermici: l'esempio dei campi geotermici italiani in esercizio: Larderello, Travale, Monte Amiata. Ist. Intern. Ric. Geot. C.N.R., Internal. Report.

Tedesco, D. and Sabroux, J. C. (1987) The determination of deep temperatures by means of the $\mathrm{CO}-\mathrm{CO}_{2-}$ $\mathrm{H}_{2}-\mathrm{H}_{2} \mathrm{O}$ geothermometer: an example using fumaroles in the Campi Flegrei, Italy. Bull. Volcanol. 49, 381-387.

Vakin, E. A., Nikitina, L. P., Shapar and Taran, Yu. A. (1982) Studies on volcanic gases and gases from hydrothermal fields in Kamchatka. Bull. Volcanol. 45, 212-216.

Weiss, A. and Roloff, G. (1963) Die Rolle organischer Derivate von glimmerartigen Schichtsilikaten bei der Bildung von Erdol. Proc. Inter. Clay Conf. Stockholm 1963, 373-378.

Zimmerie, W. (1985) New aspects on the formation of hydrocarbon source rocks. Geol. Rundschau 74, 385-416. 